\title{
RADIOCARBON IN SEAWATER INTRUDING INTO THE ISRAELI MEDITERRANEAN COASTAL AQUIFER
}

\author{
Y Yechieli ${ }^{1,2} \bullet \mathrm{O} \mathrm{Sivan}^{1,3} \bullet$ B Lazar $^{3,4} \bullet$ A Vengosh $^{5} \bullet$ D Ronen $^{6} \bullet$ B Herut $^{7}$ \\ ABSTRACT. Saline groundwaters from the Israeli coastal aquifer were analyzed for their radiocarbon and tritium content to \\ assess the rate of seawater penetration. The low ${ }^{14} \mathrm{C}$ values $(28-88 \mathrm{pMC}$ versus $100-117 \mathrm{pMC}$ in seawater) imply an apparent \\ non-recent seawater source, or water-rock interactions along the penetration route. The latter process is supported by measur- \\ able tritium values at some locations, which imply a relatively rapid rate of seawater intrusion. In other locations, low tritium \\ values ( $<2$ T.U.) indicate that recent seawater $(<50 \mathrm{yr})$ did not penetrate inland. The low $\delta^{13} \mathrm{C}$ values in saline groundwater \\ (average of $-5.3 \%$ versus $0 \%$ in seawater) indicate that the dissolved carbon pool is comprised of a significant fraction of \\ organic carbon. A linear negative correlation between $\delta^{13} \mathrm{C}$ and ${ }^{14} \mathrm{C}$ implies that this organic source is old (low ${ }^{14} \mathrm{C}$ values).
}

\section{INTRODUCTION}

Seawater intrusion is a major contributor to salinization of many coastal aquifers in the world. Determining its rate of penetration is, therefore, a very important consideration for proper utilization of groundwater in these systems. Moreover, it plays a significant role in the assessment of consequences of future sea level rise due to global climate change. The rate of seawater intrusion is usually estimated by a rise in salinity in monitoring or pumping wells and/or by theoretical hydrological models.

Very few attempts have been made to estimate the actual rate of seawater intrusion using radioactive isotopes. De Breuck and Moor (1991) and Hann (1991) reported old seawater (age of several thousands years) within the coastal aquifers of Belgium and Germany, respectively, using ${ }^{14} \mathrm{C}$ analysis. These preliminary works, however, did not take into account the effects of the various geochemical processes that can change the apparent ages significantly. Such processes are responsible for significant differences in chemical and isotopic composition between seawater and saline groundwater found in coastal aquifers adjacent to the sea (e.g. Jones et al. 1999).

The subject of fresh groundwater dating has been studied in many aquifers, including the problem of correction for water-rock interaction. Several correction methods have been proposed, including using the $\delta^{13} \mathrm{C}$ values or the $\mathrm{HCO}_{3}$ concentration (e.g. Mook 1980; Pearson and Hanshaw 1970). These studies, however, did not tackle the case of seawater intrusion.

The purpose of the present study was to examine the rate of seawater intrusion into the Israeli coastal aquifer using ${ }^{14} \mathrm{C}$ and tritium dating. The effects of several geochemical processes on dating the water were assessed.

\footnotetext{
${ }^{1}$ Geological Survey of Israel, 30 Malkhei Israel Street, Jerusalem 95501, Israel

${ }^{2}$ Corresponding author. Email: yechieli@ mail.gsi.gov.il.

${ }^{3}$ Institute of Earth Sciences, Hebrew University, Jerusalem 91904, Israel

${ }^{4}$ The Moshe Shilo Minerva Center for Marine Biogeochemistry, Hebrew University, Jerusalem 91904, Israel

${ }^{5}$ Ben-Gurion University, Beer-Sheva, Israel

${ }^{6}$ Hydrological Service, Jerusalem 91063, Israel

${ }^{7}$ Israel Oceanographic and Limnological Research, National Institute of Oceanography, Haifa 31080, Israel
}

(C) 2001 by the Arizona Board of Regents on behalf of the University of Arizona Radiocarbon, Vol 43, Nr 2B, 2001, p 773-781

Proceedings of the 17 th International ${ }^{14} \mathrm{C}$ Conference, edited by I Carmi and $\mathrm{E}$ Boaretto 


\section{HYDROGEOLOGICAL BACKGROUND}

The coastal aquifer of Israel is basically a phreatic aquifer, located along the Mediterranean coast (Figure 1). It varies in width from $7 \mathrm{~km}$ in the north to $20 \mathrm{~km}$ in the south and its thickness decreases eastward from $200 \mathrm{~m}$ near the coastline to a few meters at the foothills of the Judea Mountains. The aquifer (the Kurkar Group) consists of interlayered sand, calcareous sandstone (Kurkar), red loam (Hamra), and marine clays of Pleistocene age (Issar 1968), which overlie impervious marine clays of Pliocene age (the Saqiye Group). In the west, up to $5 \mathrm{~km}$ from the coastline, intervening clay layers divide the aquifer into several sub-aquifers. These sub-aquifers, some of which are confined, have distinct chemical compositions and hydraulic properties (Nativ and Weisbrod 1994). Seawater has intruded to different distances in various parts of the coastal aquifer (Melloul and Zeitoun, 1999). The hydraulic connection between groundwater in the different sub-aquifers and the sea is debatable. Two hypotheses have been presented suggesting that: 1) there is a fresh-saline interface configuration in all sub-aquifers (Bear and Kapuler 1981), and 2) the lower sub-aquifers are not connected to the sea (Kolton 1988).

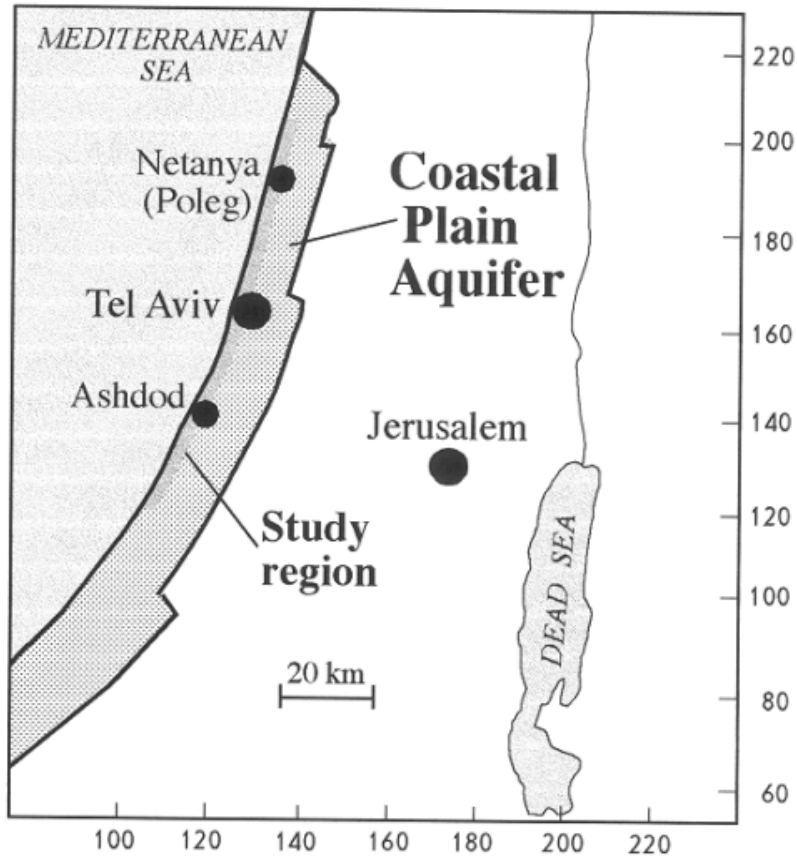

Figure 1 Location map of the Israeli Mediterranean coastal aquifer. The coordinates are of the Israeli grid.

\section{METHODS}

Fresh and saline groundwater near the Israeli shoreline was sampled for ${ }^{14} \mathrm{C}$ and tritium content. Most of the samples were obtained from observation wells using a Grundfos submersible pump. Prior to sampling, all wells were purged removing a volume of more than three times that of the water within the well casing. Additional samples were collected from pumping wells in the Tel Aviv area. ${ }^{14} \mathrm{C}$ profile was obtained in one borehole (Poleg 1), sampling groundwater both above and below the fresh-saline water interface. Samples were also collected from the shallow sea near the 
coast (distance of $1 \mathrm{~km}$ from the shoreline, water depth $<6.5 \mathrm{~m}$ ) and pore water extracted from the marine sediments below.

The size of each sample collected during $1992-1995$ for analysis of ${ }^{14} \mathrm{C}$ was $100 \mathrm{~L}$. This amount was required for ${ }^{14} \mathrm{C}$ analysis, using the conventional method of proportional counting on ethane produced from the extracted $\mathrm{CO}_{2}$. The extraction was done by acidifying the water sample with $\mathrm{HCl}$. The extracted $\mathrm{CO}_{2}$ was also used for ${ }^{13} \mathrm{C}$ analysis, using a Varian 250 mass spectrometer. The analytical error, including the instrumental error and that of the stripping process, is $\pm 1 \%$. The analytical precision of ${ }^{14} \mathrm{C}$ was $\pm 0.5 \mathrm{pMC}$. The samples collected in $1998-1999$, whose volume was less than $1 \mathrm{~L}$, were filtered in the field and analyzed by accelerator mass spectrometry (AMS). The analytical precision of ${ }^{14} \mathrm{C}$ was $\pm 0.5 \mathrm{pMC}$. $\delta^{18} \mathrm{O}$ was determined using a Varian $\mathrm{M} 250$ mass spectrometer, with a precision of $\pm 0.1 \%$. Detailed results of these samples are presented in Yechieli et al. (1997). Tritium analyses were done, after enrichment, in a LKB Quantulus scintillation counter with an maximal error of \pm 0.2 T.U.

\section{RESULTS AND DISCUSSION}

${ }^{14} \mathrm{C}$ activities of saline groundwater $(>16 \mathrm{~g} / \mathrm{l} \mathrm{Cl}$, Table 1$)$ in the examined wells near the shoreline were found to be significantly lower than that of seawater (28-88 pMC and 100-117 pMC, respectively; Table 1). ${ }^{14} \mathrm{C}$ activities in fresher groundwater were below $61 \mathrm{PMC}$. A ${ }^{14} \mathrm{C}$ profile across the freshsaline water interface in Poleg 1 borehole showed relatively uniform values between 58 and 73 pMC.

Generally, relatively low ${ }^{14} \mathrm{C}$ values of fresh groundwater (60-70 pMC), and measurable tritium, can be explained as young meteoric water that underwent interaction with calcareous rocks in the aquifer (e.g. Mook 1980). Similar values were found in many additional locations in the Israeli coastal aquifer (60-70 pMC; Bruce et al. 2001). Some samples with no tritium and low ${ }^{14} \mathrm{C}$ values ( $\left.<60 \mathrm{pMC}\right)$ were also found (Table 1), indicating a fresh component older than $\sim 50$ years. Very old fresh groundwater was found in well 36a-2 (7-20 pMC, Table 1) implying a long residence time. Following Kolton's (1988) hypothesis, it is speculated that this fresh water, found at a distance of less than $0.5 \mathrm{~km}$ from the shoreline in a deep sub-aquifer, results from a poor connection with the sea. Indeed, sites having good and poor hydraulic connection with the sea can be located based on available tritium data.

Low tritium values ( $<2$ T.U., Table 1$)$ were found in some saline groundwaters, indicating that recent seawater $(<50 \mathrm{yr})$ did not penetrate inland. Similar low tritium values were found in many other saline groundwaters in monitoring wells near the coast (Yechieli et al. 1997). Nevertheless, measurable tritium values were found in other locations (e.g. 3 T.U. in borehole 15/0 in Ashdod; Table 1) indicating penetration of relatively young seawater.

While ${ }^{14} \mathrm{C}$ values in fresh groundwater have been considered in many studies, little attention has been given to ${ }^{14} \mathrm{C}$ dating of saline groundwater in coastal aquifers. The determination of the real age of saline groundwater is complicated by several possible sources of carbon that influence the ${ }^{14} \mathrm{C}$ values, besides the process of decay. These include fresh groundwater (with variable ${ }^{14} \mathrm{C}$ activity), seawater (with variable ${ }^{14} \mathrm{C}$ activity), carbon from organic matter within both the marine and the continental sediments, and inorganic carbon (mostly calcite) also within both marine and continental sediments. Since the values of these components are not well known, it is difficult to determine their relative contribution. Hereafter, the effect of these sources on the ${ }^{14} \mathrm{C}$ dating of the saline groundwater will be examined qualitatively. 
Table 1 Isotopic composition of groundwater collected in the Israeli coastal aquifer at distances of less than $2 \mathrm{~km}$ from the coastline. Also presented are seawater and pore water samples from the continental shelf at the southeast Mediterranean Sea.

\begin{tabular}{|c|c|c|c|c|c|c|c|c|}
\hline Well & Location $^{\mathrm{a}}$ & $\begin{array}{l}\text { Date of } \\
\text { sampling }\end{array}$ & Lab nr & $\begin{array}{c}{ }^{14} \mathrm{C} \\
(\mathrm{pMC})\end{array}$ & $\begin{array}{l}\delta^{13} \mathrm{C} \\
(\%)\end{array}$ & $\begin{array}{c}\text { Tritium } \\
\text { (T.U.) }\end{array}$ & $\begin{array}{l}\mathrm{Cl} \\
\mathrm{g} / \mathrm{l}\end{array}$ & Remarks ${ }^{b}$ \\
\hline $3 a-3$ & $1049 / 1146$ & 17.9 .95 & RT2405 & 40.4 & -10.5 & 0.0 & 0.37 & Monitor \\
\hline Afridar 4 & $1087 / 1218$ & 4.8 .95 & RT2091 & 27.9 & -6.5 & 1.1 & 16.7 & Monitor \\
\hline $8 \mathrm{~b}$ & $1096 / 1230$ & 17.9 .95 & RT2093 & 37.7 & -7.0 & 0.0 & 13.9 & Monitor \\
\hline $8 b$ & $1096 / 1230$ & 27.6.99 & AAR5776 & 39.0 & -6.5 & $-^{c}$ & 8.44 & Monitor \\
\hline $8 \mathrm{~b}$ & $1096 / 1230$ & 27.6.99 & RT3285 & 32.5 & -10.8 & - & 8.44 & Monitor \\
\hline $12 b$ & $1133 / 1292$ & 12.9.94 & RT2150 & 55.2 & -6.5 & 1.2 & 19.2 & Monitor \\
\hline Ash T/1 & $1127 / 1280$ & 26.1 .95 & RT2185 & 53.1 & -6.5 & 2.1 & 10.2 & Monitor \\
\hline $15 / 0-3$ & $1110 / 1357$ & 19.12 .94 & & - & - & 3.3 & 22.1 & Monitor \\
\hline $15 / 0-3$ & $1110 / 1357$ & 26.1 .95 & RT2182 & 47.4 & -6.5 & 2.9 & 21.3 & Monitor \\
\hline $15 \mathrm{~b}$ & $1164 / 1354$ & 26.1 .95 & RT2184 & 45.8 & -5.0 & 0.0 & 7.40 & Monitor \\
\hline HIT2-2 & $1216 / 1481$ & 26.1 .95 & RT2183 & 45.6 & -8.0 & 0.0 & 20.6 & Monitor \\
\hline $36 / 0-4$ & $1312 / 1747$ & 12.2 .95 & RT2202 & 47.9 & -5.0 & 2.0 & 18.5 & Monitor \\
\hline $36 / 0-4$ & $1312 / 1747$ & 1.6 .99 & AAR5777 & 66.6 & -4.1 & - & 22.4 & Monitor \\
\hline $36 a-4$ & $1316 / 1746$ & 26.3.95 & RT2226 & 53.1 & -9.5 & - & 2.42 & Monitor \\
\hline $36 a-2$ & $1316 / 1746$ & 26.3.95 & RT2225 & 6.9 & -6.5 & 0.0 & 0.11 & Monitor \\
\hline $36 a-2$ & $1316 / 1746$ & 1.6 .99 & AAR5778 & 20.9 & -3.7 & - & 0.14 & Monitor \\
\hline $39 a$ & $1334 / 1807$ & 4.10 .94 & RT2165 & 60.7 & -5.0 & 0.1 & 2.09 & Monitor \\
\hline 42/0-1 & $1346 / 1872$ & 12.2 .95 & RT2203 & 28.1 & -7.0 & 0.0 & 3.61 & Monitor \\
\hline $42 / 0-5$ & $1346 / 1872$ & 12.2 .95 & RT2201 & 80.2 & -3.0 & 5.5 & 19.9 & Monitor \\
\hline $42 / 0-5$ & $1346 / 1872$ & 1.6 .99 & AAR5779 & 88.7 & -8.0 & - & 20.5 & Monitor \\
\hline $42 b$ & $1348 / 1871$ & 12.2 .95 & RT2200 & 51.4 & -6.0 & 2.1 & 21.4 & Monitor \\
\hline $42 b$ & $1348 / 1871$ & 1.6 .99 & AAR5780 & 61.1 & -5.4 & - & 21.4 & Monitor \\
\hline $52 \mathrm{~b}-2$ & $1393 / 2059$ & 4.10 .94 & RT2150 & 55.2 & -6.5 & - & 6.30 & Monitor \\
\hline $55 / 0-3$ & $1403 / 2119$ & 26.3 .95 & RT2227 & 57.3 & -7.5 & - & 0.70 & Monitor \\
\hline Poleg $15 \mathrm{~m}$ & $1346 / 1871$ & 16.11 .98 & AAR4885 & 60.4 & -2.5 & 7.2 & 0.63 & Monitor \\
\hline Poleg $24 \mathrm{~m}$ & $1346 / 1871$ & 16.11 .98 & AAR4886 & 66.6 & - & 6.8 & 2.64 & Monitor \\
\hline Poleg $27 \mathrm{~m}$ & $1346 / 1871$ & 16.11 .98 & AAR4887 & 62.0 & - & 2.6 & 19.5 & Monitor \\
\hline Poleg $35 \mathrm{~m}$ & $1346 / 1871$ & 16.11 .98 & AAR4888 & 58.0 & - & - & 19.4 & Monitor \\
\hline Poleg $42 \mathrm{~m}$ & $1346 / 1871$ & 16.11 .98 & AAR4889 & 72.7 & -4.0 & 2.4 & 20.2 & Monitor \\
\hline Hilton N & $128 / 166$ & 20.9 .92 & RT1734 & 61.0 & -3.7 & 3.0 & 19.8 & Pumping \\
\hline Hilton N & $128 / 166$ & 23.2.94 & RT1991 & 84.9 & -5.7 & 0.7 & 21.1 & Pumping \\
\hline Hilton N & $128 / 166$ & 19.3 .95 & RT2223 & 51.5 & -4.8 & - & 17.5 & Pumping \\
\hline Hilton S & $128 / 166$ & 19.3 .95 & RT2222 & 45.3 & -4.8 & 1.9 & 17.8 & Pumping \\
\hline Hilton E & $128 / 166$ & 20.9.92 & RT1732 & 49.0 & -5.2 & 2.8 & 20.4 & Pumping \\
\hline Hilton E & $128 / 166$ & 23.2 .94 & RT1992 & 43.9 & -4.0 & 0.9 & 16.4 & Pumping \\
\hline Hilton E & $128 / 166$ & 19.3 .95 & RT2221 & 45.1 & -4.8 & - & 19.1 & Pumping \\
\hline Plaza & $128 / 165$ & 20.9.92 & RT1733 & 46.0 & -2.5 & 1.4 & 15.0 & Pumping \\
\hline Plaza & $128 / 165$ & 23.2.94 & RT1990 & 43.9 & -2.5 & 0.9 & 15.0 & Pumping \\
\hline $\mathrm{SW}-\mathrm{Sh}$ & $128 / 166$ & 27.2 .93 & RT1820 & 117.5 & -2.5 & - & 22.2 & Seawater \\
\hline SW - Do & $128 / 164$ & 27.2 .93 & RT1821 & 115.2 & -2.1 & - & 22.2 & Seawater \\
\hline SW2 & $187 / 134$ & 8.99 & & - & - & 2.1 & 22.3 & Seawater \\
\hline SW15 & $109 / 123$ & 14.8 .95 & RT2354 & 102.7 & 0.2 & 2.2 & 22.5 & Seawater \\
\hline SW16 & $113 / 129$ & 17.9 .95 & RT2407 & 101.6 & 0.6 & - & 22.5 & Seawater \\
\hline SW-6.5 m & $1 \mathrm{~km}^{\mathrm{d}}$ & 10.95 & AAR2747 & 108.4 & 0.7 & 2.0 & 22.4 & Seawater \\
\hline PW-1 & $1 \mathrm{~km}^{\mathrm{d}}$ & 10.95 & AAR2745 & 77.2 & -6.1 & - & 22.5 & Pore water \\
\hline PW-2 & $10 \mathrm{~km}^{\mathrm{d}}$ & 10.95 & AAR2746 & 76.7 & -7.2 & - & 22.5 & Pore water \\
\hline
\end{tabular}

${ }^{\mathrm{a} C}$ Coordinates $(\mathrm{X} / \mathrm{Y})$. For locations see Figure 1.

${ }^{b}$ Monitor: samples of groundwater from monitoring wells; Pore water: samples of pore water from sea bottom sediments (sample 1 from water depth of $6.5 \mathrm{~m}$ and sample 2 from water depth of $70 \mathrm{~m}$ ) were collected with a grab sampler from depth of $0-0.25 \mathrm{~m}$ below the sediment-sea interface.

c - $=$ not analyzed

${ }^{\mathrm{d}}$ Distance seaward from the Poleg shoreline 
A significant correlation was found between salinity (represented by $\mathrm{Cl}$ concentration) and $\delta^{18} \mathrm{O}$ (Figure 2), indicating a saline end-member similar to the present Mediterranean seawater at Israel's shore. However, unlike $\mathrm{Cl}$ and $\delta^{18} \mathrm{O}$, which are conservative, it might be misleading to use the ${ }^{14} \mathrm{C}$ activity of present seawater as the value of the saline end-member. There is evidence that saline groundwater, although quite similar in major ion chemistry to seawater, differs significantly in the components of the carbonate system $\left(\mathrm{HCO}_{3},{ }^{13} \mathrm{C},{ }^{14} \mathrm{C}\right)$. These differences result from interaction between seawater and sediments along their penetration route from the sea. The isotopic composition of carbon in pore water in marine sediments supports the hypothesis regarding the influence of such processes, which reduce both $\delta^{13} \mathrm{C}$ and ${ }^{14} \mathrm{C}$ values (Table 1 and Figure $3 \mathrm{a}$ ).

The scatter of $\mathrm{Cl}$ concentrations versus ${ }^{14} \mathrm{C}$ values (Figure $3 \mathrm{~b}$ ) in groundwater demonstrates a possible two-step evolution of the penetrating seawater. First, seawater intrusion is followed by a minor decrease in salinity $(\mathrm{Cl})$, due to mixing with fresher water, and a decrease of ${ }^{14} \mathrm{C}$ values to ${ }^{45-60}$ pMC, due to interaction with old sedimentary organic and inorganic carbon. The second step involves a mixing process between the saline end-member and fresh groundwater, either old or recent.

A clear difference in $\delta^{13} \mathrm{C}$ and ${ }^{14} \mathrm{C}$ values between surface seawater ( $0 \%$ and $100-110 \mathrm{pMC}$ ) and pore water in deep sea sediments (about $-10 \%$ and $<80 \mathrm{pMC}$ ) was found by Sivan et al. (forthcoming). However, only limited data exist for pore water in shallow sea sediments, which is expected to be the main source for saline groundwater in coastal aquifers. $\delta^{13} \mathrm{C}$ values in all saline groundwaters $(-2.5$ to $-8 \%$, Table 1) were lower than in present seawater, indicating contribution from organic matter

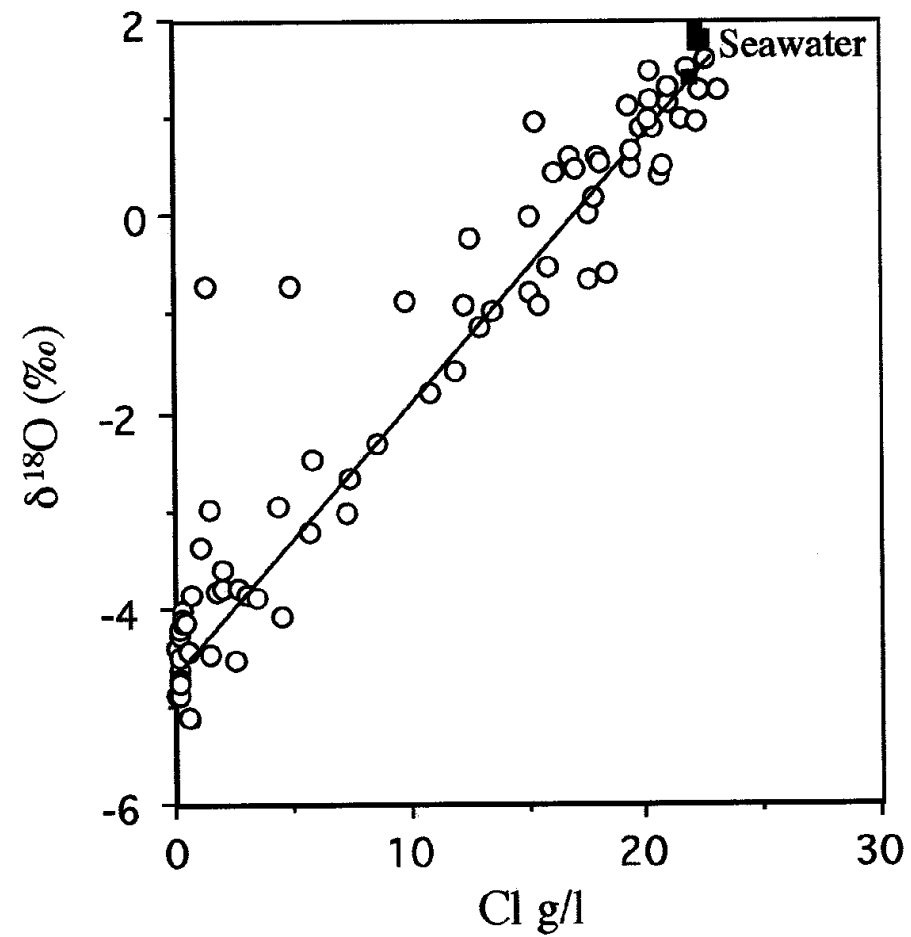

Figure $2 \mathrm{Cl}$ versus $\delta^{18} \mathrm{O}$ in groundwater in the coastal aquifer. The data presented is from this study and Yechieli et al. (1997). 
a
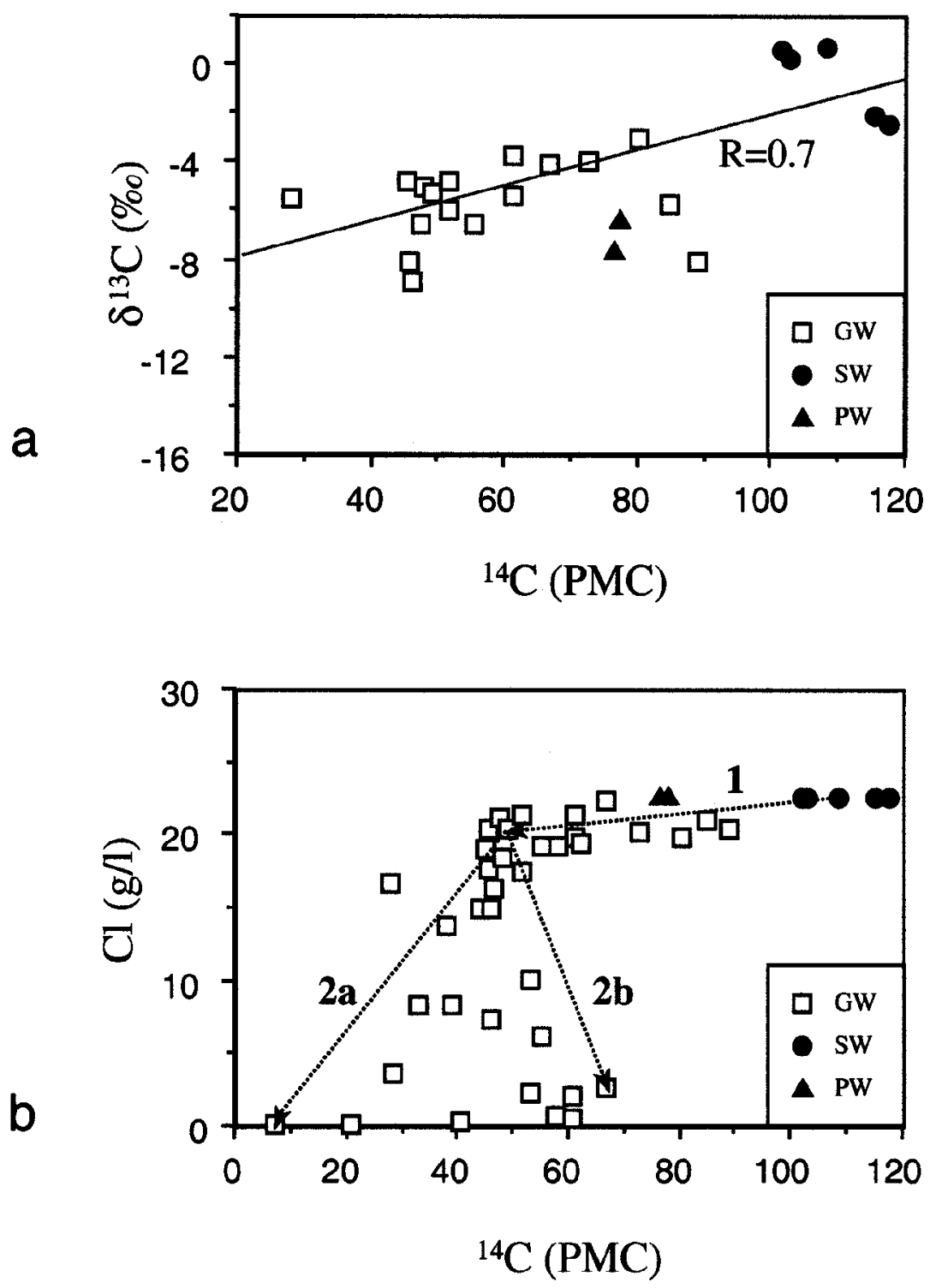

Figure $3 \mathrm{a}{ }^{13} \mathrm{C}$ versus ${ }^{14} \mathrm{C}$ in saline groundwater $(\mathrm{GW})$ in the coastal aquifer (only of samples with $>16 \mathrm{~g} / \mathrm{l} \mathrm{Cl}$ ); b. $\mathrm{Cl}$ versus ${ }^{14} \mathrm{C}$ in fresh and saline groundwater. Also shown are values of seawater (SW) and pore water (PW) from the continental shelf of the southeast Mediterranean Sea. The number 1 denotes interaction with an old carbon source and $2 \mathrm{a}$ and $2 \mathrm{~b}$ denote mixing with old and young fresh groundwater, respectively. 
(average value of $-16 \%$ was found in organic matter in Mediterranean marine sediments (Sivan et al. forthcoming). The significant negative correlation between $\delta^{13} \mathrm{C}$ and ${ }^{14} \mathrm{C}$ (Figure $3 \mathrm{~b}$ ) illustrates that this organic carbon is of low ${ }^{14} \mathrm{C}$ values. It is, therefore, important to consider this effect on ${ }^{14} \mathrm{C}$ dating. The effect of this contribution may be estimated according to the mixing ratio determined by the $\delta^{13} \mathrm{C}$ values. The average $\delta^{13} \mathrm{C}$ in the saline groundwater is $-5.3 \%$. Taking a value of $-16 \%$ and $0 \%$ o for organic matter and seawater, respectively, about $30 \%$ of the carbon in groundwater derives from organic matter. The maximal effect of organic carbon on ${ }^{14} \mathrm{C}$ values in groundwater can be estimated by assuming the ${ }^{14} \mathrm{C}$ in organic matter as close to zero. Using this assumption, values of approximately $70 \mathrm{pMC}$ in saline groundwater represent recent seawater in the aquifer. The above calculation is a simplified example since it ignores the effect of possible dissolution of old inorganic carbon. Dissolution of calcite, which is common in this system, would lower the ${ }^{14} \mathrm{C}$ activity but will not significantly affect the $\delta^{13} \mathrm{C}$ values of the original seawater.

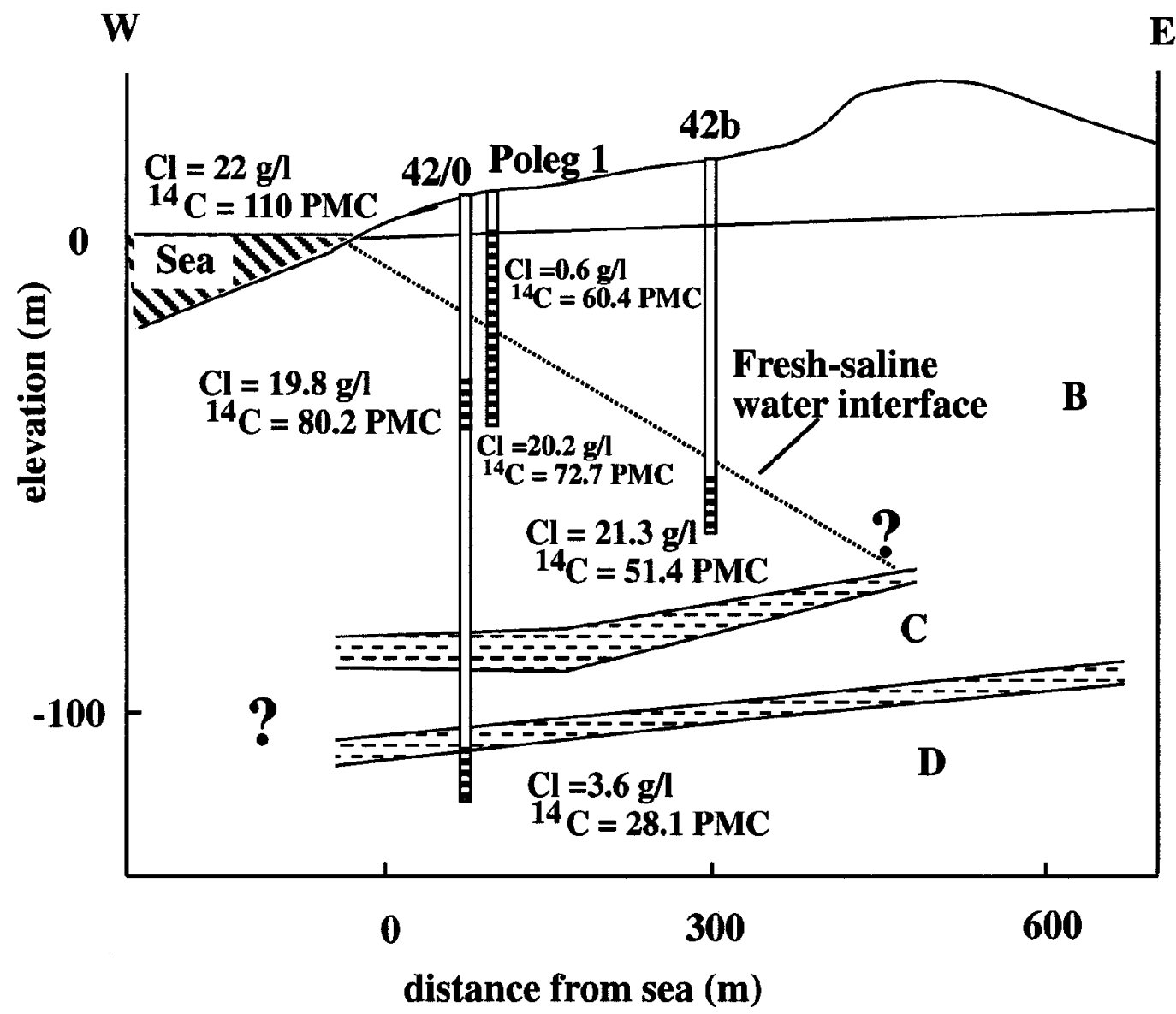

Figure 4 Schematic hydrogeological cross-section of the coastal aquifer in the Netanya (Poleg) area. The aquifer consists mainly of calcareous sandstone with several layers of marine clay. The different sub-aquifers are denoted B, C, and D. The depth of the screens in each borehole are shown as dark areas. 
In order to assess the age of saline groundwater it is necessary to determine the initial ${ }^{14} \mathrm{C}$ value of seawater entering the aquifer and to consider the chemical processes that affect this value. The determination of this seawater end-member is difficult since it has probably undergone chemical modification which changed its original chemical and isotopic composition. Therefore, the best way to determine the initial value of the saline end-member would be to use the chemical and isotopic composition of the saline groundwater closest to the shoreline as initial values of the saline component. The second step would be to calculate the age differences between wells along a cross-section from the shoreline inland. Such a cross-section was performed in the Poleg area (near Netanya; Figure 4 on previous page) where three wells contain saline groundwater with salinity similar to that of seawater. The ${ }^{14} \mathrm{C}$ activities in these wells were 80 and $51 \mathrm{pMC}$ at a distance of $70 \mathrm{~m}$ and $300 \mathrm{~m}$ from the sea (Figure 4), respectively, indicating an apparent age difference of several thousand years (Yechieli et al. 1996). However, this saline groundwater contains measurable tritium, implying a more complicated system. These observations can be explained by some of the following processes:

1. Mixing between old seawater and young freshwater from the mid 1960s as the source of tritium. Only such very high tritium values can compensate for the presence of less than $10 \%$ freshwater;

2. Interaction between recent seawater (containing tritium) and aquifer rocks, which drastically reduce ${ }^{14} \mathrm{C}$ values; and

3. Mixing of two different saline groundwaters, one very young water containing tritium and the other older, with no tritium and low ${ }^{14} \mathrm{C}$ values.

\section{CONCLUSIONS}

1. At the studied site, saline groundwater of salinity and chemical composition similar to seawater contained lower ${ }^{14} \mathrm{C}$ activities than in recent seawater. These differences may indicate both age variations and/or chemical interaction with the host rock.

2. The simultaneous finding of low ${ }^{14} \mathrm{C}$ values and high tritium content yielded complicated results regarding age determination. Several processes that may lead to such results, such as contribution from organic and inorganic carbon and mixing of several water sources, are discussed. Nevertheless, the presence of tritium indicates the presence of recent seawater in some boreholes, suggesting a rapid rate of intrusion.

3. Saline groundwaters have negative $\delta^{13} \mathrm{C}$ values indicating a significant contribution from organic carbon to the dissolved carbon pool. The linear negative correlation between $\delta^{13} \mathrm{C}$ and ${ }^{14} \mathrm{C}$ implies an old organic carbon source.

4. Based on these preliminary results, it seems that seawater intrusion into the coastal aquifer of Israel is a relatively rapid process. The presence of tritium in some saline groundwaters indicate rate of hundreds of meters in less than 40 years.

\section{ACKNOWLEDGMENTS}

We would like to thank $\mathrm{H}$ Hemo for his help in the field, I Carmi and J Minz for the ${ }^{14} \mathrm{C}$ and tritium analysis in the Weizmann Institute, E Boaretto and J Heinemier for the AMS analysis in Aarhus University, Denmark, and B Shilman for the ${ }^{13} \mathrm{C}$ analysis at the Geological Survey. We thank Gregg Davidson for his comments, which helped to improve this work. This work was supported by the Israel Science Foundation Grant 674/97 and partly by a grant from the Israeli Water Commission. 


\section{REFERENCES}

Bear J, Kapuler Y. 1981. A numerical solution for the movement of an interface in a layered coastal aquifer: Journal of Hydrology 50:273-98.

Bruce D, Friedman GM, Kaufman A, Yechieli Y. 2001. Spatial variations of radiocarbon in the coastal aquifer of Israel - indicators of open and closed systems. $\mathrm{Ra}$ diocarbon. This issue.

De Breuck W, De Moor G. 1991. The evaluation of coastal aquifer of Belgium. Hydrogeology of salt water intrusion - a selection of SWIM papers. Volume 2. p 35-48.

Hann J. 1991. Aspects of groundwater salinization in the Wittmund (East Freisland) coastal area. Hydrogeology of salt water intrusion - a selection of SWIM papers. Volume 2. p 251-70.

Issar A. 1968. Geology of the central coastal plain of Israel. Israel Journal of Earth-Sciences 17:16-29.

Jones BF, Vengosh A, Rosenthal E, Yechieli Y. 1999. Geochemical investigations. In: Bear et al., editors. Seawater intrusion in coastal aquifers - concepts, methods and practices. p 51-72.

Kolton Y. 1988. Examination of the connection between groundwater and seawater in the Pleistocene aquifer in the continental shelf of the Mediterranean sea coast in Central Israel. Tahal report 01/88/31. In Hebrew.

Melloul AJ, Zeitoun DG. 1991. A semi-empirical approach to intrusion monitoring in Israeli coastal aquifer. Seawater intrusion in coastal aquifers - concepts, methods and practices. p 543-58.

Mook WG. 1980. Carbon-14 in hydrogeological studies. In: Fritz P, Fontes J-Ch, editors. Handbook of environmental isotope geochemistry. Volume 1. The terrestrial environment. New York: Elsevier Scientific Publishers. p 49-74.

Nativ R, Weisbrod N. 1994. Hydraulic connections among sub-aquifers of the Coastal Plain Aquifer, Israel. Groundwater 32(6):997-1007.

Pearson FJ, Hanshaw BB. 1970. Sources of dissolved carbonate species in groundwater and their effects on carbon-14 dating. Vienna: IAEA. Isotope Hydrology. p 271-86.

Sivan O, Herut B, Yechieli Y, Boaretto E, Heinemeier J, Lazar B. Inverse diffusive fluxes of ${ }^{14} \mathrm{C}$ to ${ }^{12} \mathrm{C}$ in deep sea sediment - impact on pore water dating. Submitted for publication in Limnology and Oceanography. Forthcoming.

Yechieli Y, Ronen D, Vengosh A. 1996. Preliminary ${ }^{14} \mathrm{C}$ study of groundwater at the fresh-saline water interface of the Mediterranean coastal plain aquifer in Israel. Proceedings of the 14th Salt Water Intrusion Meeting. Malmo, Sweden. p 84-90.

Yechieli Y, Ronen D, Vengosh A. 1997. Isotopic measurements and groundwater dating at the fresh-saline water interface region of the Mediterranean coastal plain aquifer of Israel. Geological Survey Report GSI/ 28/96. 